\title{
The Sodomy II Trial: Does the Federal Court Set A New Precedent When Dealing with Government Expert Witness?
}

\author{
Mohd Munzil Muhamad1 \\ Ramalinggam Rajamanickam² \\ ${ }^{1}$ Lecturer, Faculty of Law, Universiti Kebangsaan Malaysia (UKM), 43600 Bangi \\ Selangor Darul Ehsan, Malaysia; mohdmunzil@ukm.edu.my \\ ${ }^{2}$ Senior Lecturer, Faculty of Law, Universiti Kebangsaan Malaysia (UKM), 43600 Bangi \\ Selangor Darul Ehsan, Malaysia; rama@ukm.edu.my
}

Doi:10.5901/mjss.2016.v7n1p397

\section{Abstract}

On 10th February 2015, the highest Court in Malaysia, the Federal Court delivered its decision on an appeal made by a wellknown politician, Dato' Seri Anwar bin Ibrahim (DSAI) who has been convicted for committing carnal intercourse against the complainant, Mohd Saiful Bukhari bin Azlan. Within the Malaysian context, this case is commonly known as the "Sodomy II Trial" since the accused was also charged with a similar offence in a separate case back in 1998. In this recent case, the Court had to deal with several types of evidence including expert witnesses. DNA experts were called by both parties during trial but during the appeal at the Court of Appeal, the Court favoured the evidence given by the government experts over the experts called by the Defence. In the Federal Court, the evidence given by the DNA experts have been re-evaluated and the Federal Court also favoured the evidence given by the government experts. In the light of the approach taken by the Court when dealing with expert evidence, this article addresses the issue of preferential treatment given to the government expert witnesses in Malaysia by taking into account the decision of the Malaysian Federal Court in the Sodomy II Trial. The article is qualitative in nature. It is a pure legal research whereby it focuses only on the legal component. This article found that the Malaysian courts have deviated from the precedent set by the Supreme Court in Munusamy v Public Prosecutor [1987] 1 MLJ 492 regarding the issue of expert evidence.

Keywords: expert witness; DNA; preferential treatment

\section{Introduction}

Forensic evidence is now routinely used in the criminal justice process. The discriminatory power of forensic evidence like the use of forensic DNA analysis not only gives the authority an invaluable tool in identifying crime perpetrators but also makes it easier for the prosecution to prove the case against the accused.

However, one must not forget that forensic evidence falls within the matter which is outside the court's knowledge. Forensic analysis is conducted by an expert witness who will later present the result of the analysis in court. In Malaysia, forensic analysis on behalf of the prosecution is normally conducted either by experts from the Chemistry Department of Malaysia (CDM) or experts from the Royal Malaysia Police Forensic Laboratory (RMPFL). ${ }^{1}$ One similarity between these experts is that all of them are government experts.

In reality, though it is not impossible, it is an uphill task for the defence to challenge the testimony given by government expert witnesses. This is due to the fact that the preferential treatment given by law and precedent to those experts. Only in rare occasion, the court would reject their testimony. One example can be seen in Public Prosecutor $v$ Azman bin Ismail \& Ors [2007] 3 MLJ $628(\mathrm{HC})$ at para [48]-[49], when the High Court rejected DNA evidence presented by the prosecution after finding that the expert witness who conducted the analysis was not a competent expert witness.

There are two main focusses of this article. First, it explains the preferential treatment given by law and precedent to government expert witnesses in Malaysia. As a result of the preferential treatment, it is not too far- fetched to suggest it is an easy task for the prosecution in Malaysia to prove the admissibility of expert evidence that it wishes to use during trials.

1 "Forensic" Department of Chemistry, Malaysia, Ministry of Science, Technology \& Innovation <www.kimia.gov.my>; and No: SAMM 586" Department of Standards Malaysia < www.standardsmalaysia.gov.my> at 1-2. RMPFL is accredited to conduct DNA profiling, ballistics (firearm identification, document examination and vehicle examination. 
Secondly, this article also highlights the implication that resulted from the recent judgment of the Federal Court in the case that involved Dato' Seri Anwar bin Ibrahim, the former Deputy Prime Minister of Malaysia who faced trial for a sodomy charge. Having charged for the similar offence in a separate case in 2000 , this recent case is commonly known by the general public as the Sodomy II trial. This article argues that the judgment of the Court has indirectly expanded this preferential treatment given to government expert witness by deviating from the precedent set by the Supreme Court in Munusamy v Public Prosecutor [1987] 1 MLJ 492 regarding the issue of expert evidence.

\title{
2. Preferential Treatment Enjoyed by Government Expert Witnesses
}

\subsection{Presumed to be Competent}

Evidence of expert witness is admissible under $s 45$ of Evidence Act 1950. The two tests that need to be satisfied before expert evidence can be admitted was summarised by the Supreme Court in Junaidi bin Abdullah v Public Prosecutor [1993] 3 MLJ 217 (SC) per Mohamed Azmi SCJ as the following:

\begin{abstract}
In our view, the test to be applied for the purpose of $s 45$ of the Evidence Act 1950 is this. First, does the nature of the evidence require special skill? Second, if so, has the witness acquired the necessary skill either by academic qualification or experience so that he has adequate knowledge to express an opinion on the matter under enquiry? The answer to both questions must necessarily depend on the facts of each particular case. ([1993] 3 MLJ 217 (SC) at p. 229)
\end{abstract}

Firstly, the evidence must be the one that requires special skill. Secondly, the person giving the evidence must be a qualified person. As can be seen in the above passage, the Court generally will examine his or her academic qualification to determine whether a person is an expert. However, the Supreme Court in the same case had also explained that the competency of government expert witness may be presumed without the need to enquire their qualification if the nature of expert evidence is an uncomplicated matter. We reproduce the judgment of the Court on this matter:

We were therefore of the opinion that since the evidence sought to be proved by the prosecution was limited only to serviceability of an ordinary revolver, Mr Cheong (PW6), a chemist in the chemistry department, was competent to give expert evidence of such an uncomplicated matter. In the circumstances of this case, the court was entitled to accept his position as a government chemist as sufficient, without going into his academic qualification or experience. ([1993] 3 MLJ 217 (SC) at p. 230) (emphasis added).

The above quotation shows that when the expert's testimony is confined to an uncomplicated matter, the court may accept expert evidence without examining his or her qualification or experience as an expert. It should be noted that the principle derived from the case is only applicable when the matter involved is uncomplicated.

\subsection{Presumed to have Conducted Analysis in a Correct Manner}

Apart from the presumption of their competency, illustration (e) of s 114 of the Evidence Act 1950 allows courts to presume that any forensic analysis conducted by the government expert witness has been conducted in a correct manner. Illustration (e) of s 114 states:

The Court may presume-

(e) that judicial and official acts have been regularly performed;

This presumption was invoked by the High Court in Pendakwa Raya v Kek Leong Peng [1992] 3 CLJ (Rep) 234 $(\mathrm{HC})$ at p. 237 when it was presumed that the government chemist who analysed a quantity of illicit drugs had taken the necessary precautions to ensure that the representative sample he removed was not tampered with in order to be able to carry out a correct analysis.

\subsection{Testimony on Uncomplicated Matter Accepted on Its Face Value}

Testimony of government expert witness may be accepted on its face value if it involves an "uncomplicated matter, when expert opinion confined only to the elementary nature and identity of a substance". This precedent is set by the Supreme 
Court in Munusamy v Public Prosecutor [1987] 1 MLJ 492 (SC) at 495- 496 as the following:

The only reason for sending the exhibits to the chemist is to determine their identity and to confirm what other witnesses have suspected. This type of opinion must in our view be distinguished from opinions which are of very technical or complicated nature, such as those given by handwriting, trade mark, copy right or ballistic experts. Without being derogatory it is common knowledge that even animals, such as snuff dogs when sufficiently trained, are able to detect certain dangerous drugs. We are therefore of the view, that is this type of cases where the opinion of the chemist is confined only to the elementary nature and identity of substance, the court is entitled to accept the opinion of the expert on its face value, unless it is inherently incredible or the defence calls evidence in rebuttal by another expert to contradict the opinion. So long as some credible evidence is given by the chemist to support his opinion, there is no necessity for him to go into details of what he did in the laboratory, step by step. (emphasis added)

\section{Testimony Accepted on Its Face Value: Now Applies to All types of Expert Witness Evidence}

\subsection{How did it starts?}

First of all, it is important to note that Munusamy was referred to and followed by three previous cases decided by the apex court as can be seen in Public Prosecutor v Lam San [1991] 3 MLJ 426 (SC), Khoo Hi Chiang v Public Prosecutor and another appeal [1994] 1 MLJ 265 (SC) and Balachandran v Public Prosecutor [2005] 2 MLJ 301. Out of these three cases, the Courts in Lam San at p. 426-427 and Khoo Hi Chiang at p. 272 reproduced the passage in Munusamy in full as in the above. On the other hand, in Balachandran, the Court only quoted:

It has been held by the trilogy of the (then) Supreme Court cases of Munusamy v PP [1987] 1 MLJ 492, PP v Lam Sam [1991] 3 MLJ 426 and Khoo Hi Chiang v PP [1994] 1 MLJ 265 that the court is entitled to accept the evidence of the chemist on its face value without the necessity for him to go into details of what he did in the laboratory step by step unless it is inherently incredible or the defence calls evidence in rebuttal by another expert. ([2005] 2 MLJ 301 at para [17]) (emphasis added).

However, we argue that the judgment in these three cases with regard to expert witness must be viewed in the nature and context of expert evidence adduced in those cases. These three cases involved expert evidence on drug analysis. Drug analysis normally involves analysis as to the weight and the types of drugs. Thus, the applicability of the precedent set in Munusamy in these three cases can be regarded as appropriate and does not raise any concern.

An example where Malaysian courts are willing to accept testimony given by a government expert witness on its face value even when it involves complicated matters can be seen from what had transpired in Public Prosecutor $v$ Muhammad Rasid bin Hashim [2011] 7 MLJ 845 (HC). When evaluating the government expert witness testimony on DNA evidence, the High Court at para [46] held that:

In the case of Munusamy v Public Prosecutor [1987] 1 MLJ 492 [SC] learned Justice Mohd Azmi SCJ had said that unless the evidence of the chemist was inherently incredible or the defence called evidence in rebuttal by another expert to contradict the opinion, the court was entitled to accept the opinion of the expert on its face value. I had found that there was nothing inherently incredible about the evidence of SP8 on his findings on the DNA profiling on the specimens analysed by him. And I noted too that there was no serious challenge mounted by the defence on the methodology as employed by SP8 in the course of his DNA analysis and definitely there was no introduction by the defence of rebuttal evidence of another expert to contradict SP8's opinion. (emphasis added).

It is important to note that, the High Court in the above case also did not cite the original passage as per decided in Munusamy in full. It can be seen that the sentences which highlighted the condition when the expert witness testimony can be accepted on its face value was omitted by the Court. The question is can the precedent in Munusamy also be applied to the testimony of expert evidence regarding DNA analysis?

As explained earlier, the precedent in Munusamy with regard to accepting expert witness testimony on its face value should only apply when the testimony involves an uncomplicated matter. Due to the nature and the complexity in the process of DNA analysis, it is wrong to say that expert testimony on DNA analysis should also fall within that category. ${ }^{2}$ In fact, the DNA analysis is much more complicated and complex compared to some examples of complicated matter given by the Court in Munusamy; the handwriting, trade mark, copy right or ballistic experts. Thus, it is submitted

2 See Erin Kruger "Accusing DNA" (2008) 14 Parallax 101 at p 103-105. This article explains briefly the step by step process in DNA analysis. It shows the complexity in the DNA analysis process. 
that the High Court in this case had not only failed to observe the doctrine of stare decisis ${ }^{3}$ but also had modified the principle laid down by the Supreme Court in Munusamy which it was bound to follow.

\title{
3.2 The Implication from the Federal Court's Judgment in the Sodomy II Trial
}

On 10th February 2015, the Federal Court delivered the judgment for the Sodomy II trial. Coincidentally, the testimony of government expert witnesses in this case also involved DNA evidence. The appellant in this case had challenged the DNA analysis conducted by government expert witnesses through gruelling cross-examination and by calling rebuttal expert evidence. Despite that, the Court was in favour of the testimony given by the government expert witnesses over the defence expert witnesses. After concluding that the evidence falls within the category of expert opinion (the first test in s 45 and as explained in Junaidi in the above), the Court made the following observation: ${ }^{4}$

\begin{abstract}
As regards the opinion of an expert, it was observed in Munusamy v Public Prosecutor [1987] 1 MLJ 492 as follows: "... the court is entitled to accept the opinion of the expert on its face value, unless it is inherently incredible or the defence calls evidence in rebuttal by another expert to contradict the opinion. So long as some credible evidence is given by the chemist to support his opinion, there is no necessity for him to go into details of what he did in the laboratory, step by step."
\end{abstract}

(Public Prosecutor v Lam San [1991] 1 CLJ (rep) 391; Khoo Hi Chiang v Public Prosecutor [1994] 2 CLJ 151)

Having considered the totality of the evidence, and having taken into consideration the above discussion we have no doubt that the appellant failed to discredit PW5 and PW6. There was nothing inherently incredible about PW5 and PW6's evidence.

As can be seen in above, the Federal Court like in Balachandran and Muhammad Rasid also omitted the portion which highlighted the circumstances when testimony of expert witnesses can be accepted on its face value as we mentioned earlier.

We argue that by using the phrase "As regards the opinion of an expert" as in the above and by not citing the passage in Munusamy in full, the Court has indirectly suggested that with regard to expert opinion, the current law in Malaysia is that the Malaysian courts are now willing to accept testimony given by government expert witness on its face value even when it involves complicated matter like DNA analysis ${ }^{5}$ unless it is proven highly incredible or the defence calls evidence in rebuttal by another expert to contradict the opinion. In this respect, the court had thus deviated from the original precedent set in Munusamy.

It is important to note that Munusamy was decided by the Supreme Court, the apex court of the country at that time. The Sodomy II trial was decided by the Federal Court, which is the current apex court of the country. Being the current apex court of the country, the principle set by the Federal Court's judgment in the Sodomy II trial prevails, represents the current law on this issue and is bound to be followed by the lower courts. ${ }^{6}$

\section{Conclusion}

In this article, we argue that the Federal Court's judgment in the Sodomy II trial has indirectly set a new precedent with regard to expert witness evidence in Malaysia. Literal interpretation from the judgment suggests that courts are now willing to accept all types of expert evidence including forensic evidence adduced by government expert witnesses on its face value without the need to assess the nitty-gritty of how the analysis process was conducted. If this is the true intention of the court, we argue that this precedent would further add to the disadvantage of the defence in criminal trials.

Although in theory the defence may rebut prosecution expert evidence by exercising the trial safeguards given to them such as the right to cross-examination or calling rebuttal expert evidence, in reality, effective utilisation of these two

\footnotetext{
${ }^{3}$ See Public Prosecutor v Datuk Tan Cheng Swee \& Anor [1980] 2 MLJ 276 (FC) at p 277. Per Chang Min Tat FJ; "It is however necessary to reaffirm the doctrine of stare decisis which the Federal Court accepts unreservedly and which it expects the High and other inferior Courts in a common law system such as ours, to follow similarly".

${ }^{4}$ Dato' Seri Anwar Bin Ibrahim v Public Prosecutor 05-47-03/2014(W) 10 February 2015 at para [172]-[173].

${ }^{5}$ See At para [104]-[173]. The complexity in DNA analysis can be seen from the lengthy discussion made by the Federal Court in Sodomy II trial.

${ }^{6}$ See also Dalip Bhagwan Singh v Public Prosecutor [1998] 1 MLJ 1 (FC) at p 14. "If the House of Lords, and by analogy, Federal Court, departs from its previous decision when it is right to do so in the circumstances set out above, then also by necessary implication, its decision represents the present state of the law. When two decisions of the Federal Court conflict on a point of law, the later decision therefore, for the same reasons, prevails over the earlier decision."
} 
rights are easier said than done. For example, cross-examination of an expert witness who testified on forensic evidence can only be effectively made if the defence lawyer also has sufficient knowledge on the subject matter. Without special training, the defence lawyer would be easily overpowered by the expert witness. ${ }^{7}$ On the other hand, the right to call rebuttal expert evidence is only available to an accused who has strong financial sources (Van der Walt, 2001, p. 309). It is highly improbable to expect an indigent accused would be able to get access to forensic expert to assist his or her case when it is an open secret in Malaysia that many accused cannot even afford to hire a lawyer to represent them during trials.

In addition, the latest precedent also increases the risk of accepting unreliable expert evidence during trials. It must be noted that the current admissibility rule in Malaysia does not require the party who would like to adduce expert evidence to prove "evidentiary reliability." As we explained earlier, there are only two tests that need to be satisfied as per s 45 of Evidence Act 1950. The reliability test is currently part of the tests that need to be fulfilled and adopted in other Common Law jurisdictions before expert evidence can be admitted. For example, Rule 702 of the Federal Rules of Evidence in the United States not only requires the techniques used by expert evidence in the analysis must be proven as reliable but also requires the court to examine whether the expert has reliably applied the principles and methods to the facts of the case (See also Daubert v Merrell Dow Pharmaceuticals, Inc. 509 US 579 (1993) at p. 593-594). Thus, courts should take an active role to assess the reliability of expert opinion before it can be admitted. To put it in another way, no expert evidence should be accepted on its face value.

\section{References}

Balachandran v Public Prosecutor [2005] 2 MLJ 301

Dalip Bhagwan Singh v Public Prosecutor [1998] 1 MLJ 1 (FC)

Erin Kruger. (2008). Accusing DNA, 14 Parallax 101

Dato' Seri Anwar bin Ibrahim v Public Prosecutor 05-47-03/2014(W) 10 $10^{\text {th }}$ February 2015

Daubert v Merrell Dow Pharmaceuticals, Inc. 509 US 579 (1993)

Gary Edmond and Mehera San Roque. (2012). "The Cool Crucible: Forensic Science and the Frailty of the Criminal Trial, 24 CICJ 51

Junaidi bin Abdullah v Public Prosecutor [1993] 3 MLJ 217 (SC)

Khoo Hi Chiang v Public Prosecutor and another appeal [1994] 1 MLJ 265 (SC)

Lirieka Meintjes-Van der Walt. (2001).Expert Evidence and the Right to Fair Trial: A Comparative Perspective, 17 SAJHR 301

Munusamy v Public Prosecutor [1987] 1 MLJ 492 (SC)

Pendakwa Raya v Kek Leong Peng [1992] 3 CLJ (Rep) 234 (HC)

Public Prosecutor v Azman bin Ismail \& Ors [2007] 3 MLJ 628 (HC)

Public Prosecutor v Datuk Tan Cheng Swee \& Anor [1980] 2 MLJ 276 (FC)

Public Prosecutor v Lam San [1991] 3 MLJ 426 (SC)

Public Prosecutor v Muhammad Rasid bin Hashim [2011] 7 MLJ 845 (HC)

www.kimia.gov.my

www.standardsmalaysia.gov.my

\footnotetext{
${ }^{7}$ Lirieka Meintjes-Van der Walt "Expert Evidence and the Right to Fair Trial: A Comparative Perspective" (2001) 17 SAJHR 301 at p 308; and See also Gary Edmond and Mehera San Roque "The Cool Crucible: Forensic Science and the Frailty of the Criminal Trial" (2012) 24 CICJ 51 at p 56: Discussed on the ineffectiveness of cross-examination in exposing the methodological weaknesses methodological weakness, exaggeration or even fraud in forensic evidence.
} 